\title{
Molecular and morphological identification of an uncommon centrolophid fish
}

\author{
Communication
}

Valentina Milana ${ }^{1, \star}$, Andrea Fusari², Anna Rita Rossi ${ }^{1}$, Luciana Sola1

'Department of Biology and Biotechnology "C. Darwin", Sapienza - University of Rome,

00161 Rome, Italy

${ }^{2}$ A.Ge.l. - Agriculture and Fish Management, 00194 Rome, Italy

Received 03 December 2010; Accepted 29 January 2011

Abstract: The use of both morphological and molecular methods has allowed a fast and reliable species assignment of a fish that local fishermen with over thirty years of experience had never seen before. The identified species, Schedophilus medusophagus, is rare along Italian coasts, and this is the first documented record in the Central Tyrrhenian Sea for over 35 years. Its abundance should be evaluated on a continuous basis, as it might reflect biological consequences of environmental and climatic change. The mitochondrial sequences obtained in this study constitute a useful molecular tag for future research and may contribute to the phylogenetic debate on the status of the genus Schedophilus, of which $S$. medusophagus is the type species. Based on the existing literature, these preliminary molecular data support the hypothesis that the genus is not monophyletic.

Keywords: $\mathrm{COI} \bullet$ Cornish blackfish • Mediterranean Sea • mtDNA • rare fish • Schedophilus medusophagus

(c) Versita Sp. z 0.0 .

\section{Introduction}

Fish species are traditionally identified based on external morphological characters [1]. Nevertheless, classical identification can sometimes be rather difficult, for example when considering early-life stages and juvenile specimens; or in cases of species showing morphological interspecific similarity or high intraspecific variability. The development in the past two decades of molecular approaches based on PCR amplification, and of online sequence databases such as GenBank, EMBL-Bank and DDBJ, have considerably helped the identification of fish species. For example, 18 cryptic species have been recently identified [2] in a genus Schindleria which previously included only three species. As recently revised by Teletchea [3], the establishment of a DNA barcoding system, i.e. a molecular barcode inventory of known animal taxa, based on the mitochondrial gene cytochrome c oxidase I (COI) was proposed by Hebert et al. [4]. In the same year, Tautz et al. [5] emphasized the need of a DNAbased taxonomy system, which can act as a scaffold for taxonomic knowledge and as a convenient tool for species identification and description, still to be "firmly anchored within the knowledge, concepts, techniques and infrastructure of traditional taxonomy". Recently, Teletchea [6] drew this same conclusion "after 7 years and 1000 citations". Several studies [e.g., 7,8] document the benefit of complementing the traditional taxonomic data (morphology-based species identification) with molecular tools (DNA-based species identification) for fish species identification.

This study combined morphological and molecular approaches for the species assignment of a teleost collected in the Central Tyrrhenian Sea, that fishermen with over thirty years of experience in the area had never seen before. The molecular approach was carried out using several mitochondrial genes which, due to their characteristics (high copy number per cell, lack of introns, limited recombination, haploid mode of 
inheritance and appropriate rate of evolution), are easier and more straightforward to apply than nuclear DNA [3].

\section{Experimental Procedures}

On July 2008, a single specimen of an unknown fish was caught in the Central Tyrrhenian Sea, near Anzio (Italy), at a depth of between 80 to 100 meters. The specimen was measured, frozen $10 \mathrm{~h}$ after the catch, and kept at $-20^{\circ} \mathrm{C}$ for 20 months. In March 2010 , the specimen was defrosted and external morphological features and meristic characters were collected. No morphometric data were collected, as the front of the head of the specimen was damaged, probably by the trawl net.

Total genomic DNA was extracted from a pectoral fin clip of the specimen using the method of Aljanabi and Martinez [9]. Fragments of four mitochondrial regions - 16S rDNA (16S), cytochrome c oxidase I (COI), cytochrome b (Cyt $b$ ) and control region (CR) were amplified using the following primers: L2510-16S and H3084-16S [10] for the 16S rDNA, GluFor [11] and 34Rev [12] for the Cyt $b$, FishF1 and FishR2 [13] for the $\mathrm{COI}$, and Lpro2 and HdL1 [14] for the CR. PCR reactions were carried out in a total volume of $10 \mu \mathrm{l}$, containing $1 \mu \mathrm{l}$ of 10X Buffer (BIOLINE, London, U.K.), $0.3 \mu \mathrm{l}$ of $\mathrm{MgCl}_{2}$ $(50 \mathrm{mM}), 0.2 \mu \mathrm{l}$ of dNTP $(2.5 \mathrm{mM}), 0.1 \mu \mathrm{l}$ of each primer (100 mM), $0.07 \mu \mathrm{l}$ of $5 \mathrm{U} \mathrm{\mu l}^{-1}$ BIOTAQ (Gaithersburg, MD, USA), DNA polymerase and 10-100 ng of template. PCR was performed in a Biometra Thermocycler with an initial denaturation of $2 \mathrm{~min}$ at $95^{\circ} \mathrm{C}$ followed by 30 cycles of $30 \mathrm{~s}$ at $94^{\circ} \mathrm{C}, 30 \mathrm{~s}$ at $54^{\circ} \mathrm{C}, 1 \mathrm{~min}$ at $72^{\circ} \mathrm{C}$ and a final extension for $10 \mathrm{~min}$ at $72^{\circ} \mathrm{C}$. PCR products were purified with SureClean Plus (Bioline) and sequenced on both strands with an automated DNA sequencer (BMR Genomics) using the same primers as those for the PCR. All sequences were visually verified on a chromatogram with Chromas Lite software version 2.01 (Technelysium Pty Ltd., Helensvale, Australia), aligned with the Clustal X program [15] for the complete reconstruction of the four mtDNA sequences. The four sequences were deposited in GenBank (accession numbers: HQ455052-HQ455055). Each sequence was BLASTed in GenBank, the NIH genetic sequence database; the COI sequence was also BLASTed in the Barcode of Life Data Systems (BOLD).

\section{Results and Discussion}

The specimen (Figure 1) was approximately $14.6 \mathrm{~cm}$ in length and $29.9 \mathrm{~g}$ in weight, and when freshly caught was dark red, dorsally purplish and ventrally light brown. The head was lighter than the body; and numerous pigment dots were present. The body was elongated, with a single, long, continuous dorsal fin. Meristic counts, collected using a stereomicroscope, were: 50 dorsal fin spines plus soft rays, 30 anal fin spines plus soft rays, 22 caudal fin rays, 19 pectoral fin rays, 4 ventral fin rays. There were 11 gill rakers on the first arch. Twelve spines were also visible on the margin of the preopercule. The collected morphological data confirmed that the specimen does not belong to any of the common Mediterranean families.

The molecular approach allowed us to circumscribe the number of possible teleost taxa to be considered for the morphological identification, up to the species level. The length of the studied sequences (some including the forward and the reverse primer sequences, or part of them) was: $646 \mathrm{bp}$ for the $16 \mathrm{~S}$ rDNA, $437 \mathrm{bp}$ for the Cyt b, $629 \mathrm{bp}$ for the COI, and $422 \mathrm{bp}$ for the CR. The results of BLAST searches in GenBank and $B O L D$ are given in Tables 1 and 2, respectively. The Cyt $b$ and, mainly, the $\mathrm{COI}$ sequences provided the most

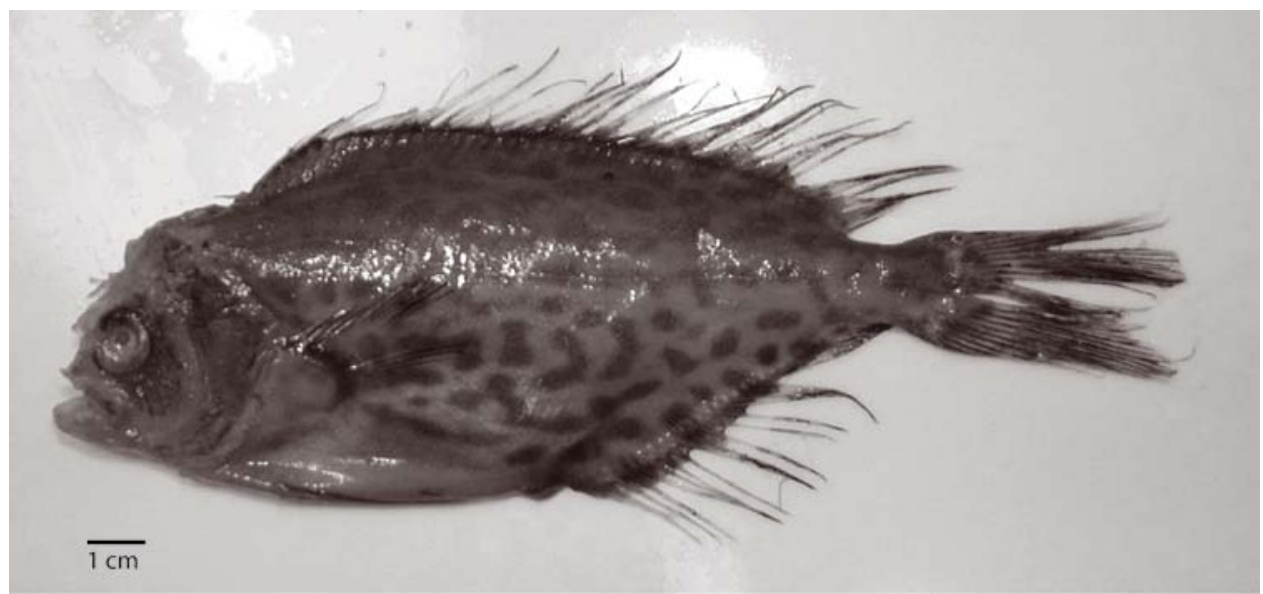

Figure 1. The specimen collected in the Tyrrhenian Sea (Photo: A. Fusari). 


\begin{tabular}{|c|c|c|c|c|c|}
\hline \multirow[t]{2}{*}{ FAMILY } & \multirow[t]{2}{*}{ SPECIES } & \multicolumn{4}{|c|}{ MAXIMUM IDENTITY (\%) } \\
\hline & & $16 S$ & Cyt b & $\mathrm{COI}$ & $\mathrm{CR}$ \\
\hline \multirow[t]{11}{*}{ Centrolophidae } & Schedophilus ovalis & 98 & 90 & 90 & $\mathrm{n} / \mathrm{a}$ \\
\hline & Schedophilus labyrinthicus & $\mathrm{n} / \mathrm{a}$ & $\mathrm{n} / \mathrm{a}$ & 90 & $\mathrm{n} / \mathrm{a}$ \\
\hline & Schedophilus velaini & $\mathrm{n} / \mathrm{a}$ & 87 & $\mathrm{n} / \mathrm{a}$ & $\mathrm{n} / \mathrm{a}$ \\
\hline & Seriolella caerulea & 98 & 89 & 91 & $\mathrm{n} / \mathrm{a}$ \\
\hline & Seriolella punctata & 98 & 89 & 90 & 79 \\
\hline & Seriolella porosa & $\mathrm{n} / \mathrm{a}$ & $n / a$ & 90 & $\mathrm{n} / \mathrm{a}$ \\
\hline & Centrolophus niger & 98 & 88 & 90 & $\mathrm{n} / \mathrm{a}$ \\
\hline & Icichthys lockingtoni & 98 & 88 & 91 & $\mathrm{n} / \mathrm{a}$ \\
\hline & Hyperoglyphe japonica & 98 & 89 & 90 & $\mathrm{n} / \mathrm{a}$ \\
\hline & Hyperoglyphe antarctica & $n / a$ & $\mathrm{n} / \mathrm{a}$ & 90 & $\mathrm{n} / \mathrm{a}$ \\
\hline & Hyperoglyphe moselii & $\mathrm{n} / \mathrm{a}$ & $\mathrm{n} / \mathrm{a}$ & 90 & $\mathrm{n} / \mathrm{a}$ \\
\hline \multirow[t]{2}{*}{ Nomeidae } & Cubiceps pauciradiatus & 92 & 85 & $\mathrm{n} / \mathrm{a}$ & 87 \\
\hline & Psenes cyanophrys & 91 & 80 & $n / a$ & 78 \\
\hline
\end{tabular}

Table 1. BLAST search results in the GenBank database for the four mtDNA genes of the unknown fish; n/a: not available.

discriminating information for the identification of the specimen. This is congruent with expectations. Indeed, according to Tautz et al. [5], sequences encoding ribosomal small subunit RNAs, whether of nuclear and mitochondrial origin, are highly conserved and thus not particularly useful for discriminating closely-related species. On the other hand, the mitochondrial CR is one of the fastest diverging regions of mtDNA. Therefore, it is more commonly used for the identification of genetically differentiated populations.

On the basis of genetic data, the specimen appears to belong to the family Centrolophidae, with a $100 \%$ probability of placement after a BLAST search in the BOLD data base (Table 2), which also places it in the genus Schedophilus, with a $98 \%$ probability (Table 2). As far as the species assignment is concerned (Table 3), the top match is with Schedophilus huttoni, which is, however, distributed in the South Pacific and Western Indian Oceans, and along the South African coast of the Atlantic Ocean. With the exception of Schedophilus ovalis, none of the remaining top-match species inhabits the Mediterranean Sea, or the Red Sea. This latter issue is particularly important given that one of our possible hypotheses was that we were dealing with an alien Lessepsian fish.

On the basis of the molecular data, we went back to morphological keys which are specific to the Centrolophidae [16-19] and we identified the specimen as a juvenile of the species Schedophilus medusophagus Cocco, 1839, which can be easily distinguished from the Mediterranean, congeneric, $S$. ovalis on the basis of meristic traits, and particularly due to the median fin

\begin{tabular}{l|lc}
\hline TAXONOMIC LEVEL & TAXON ASSIGNMENT & Pp (\%) \\
\hline \hline Phylum & Chordata & 100 \\
Class & Actinopterygii & 100 \\
Order & Perciformes & 100 \\
Family & Centrolophidae & 100 \\
Genus & Schedophilus & 98 \\
\hline
\end{tabular}

Table 2. BLAST search results in the BOLD database for the COI sequence of the unknown fish. Pp (\%), probability of placement.

\begin{tabular}{l|c}
\hline SPECIES & Ss (\%) \\
\hline \hline Schedophilus huttoni & 98 \\
Icichthys lockingtoni & 92 \\
Tubbia tasmanica & 92 \\
Schedophilus ovalis & 91 \\
Schedophilus maculatus & 91 \\
Schedophilus velaini & 91 \\
Schedophilus labyrinthicus & 91 \\
Seriolella caerulea & 91 \\
Seriolella porosa & 91 \\
Seriolella punctata & 91 \\
Hyperoglyphe japonica & 91 \\
\hline
\end{tabular}

Table 3. Top 11 matches for the COI sequence of the unknown fish within the Centrolophidae family detected with the BLAST search in the BOLD database. Ss (\%), specimen similarity. 
spines which, in the former, are weak and difficult to distinguish from rays, and, in the latter, strong and easily distinguishable.

The Cornish blackfish, $S$. medusophagus, is a subtropical mesopelagic species characterized by a vertical-age distribution. Juveniles and young adults live in the surface layers of the sea, and are commonly associated with pelagic medusae or floating objects, while adults are found at 500-600 m depth. S. medusophagus is distributed in the North-Eastern and North-Western Atlantic, and in the Western Mediterranean [16,17,20]. It is rare along the Italian coasts, although Bini [20] and Tortonese [16] reported its presence on the west coast of Italy from museum specimens coming from the Ligurian Sea, Naples and Sicily. Thus, this is the first documented record of the species in the Central Tyrrhenian Sea in over 35 years. As far as the Adriatic Sea is concerned, Dulčić [21] reported the first capture of larvae of $S$. medusophagus in the eastern central Adriatic and proposed that this record could represent an extension of the species range, compared to previous records for the species in the area [22,23]. Dulčić [21] also emphasized that, in the same period (mid 1990s), along with the Cornish blackfish, other mesopelagic species uncommon in the area had been recorded, and suggested that all these records could be connected to environmental factors, including increasing temperature. A similar explanation has also been hypothesized by Corsini-Foka and Frantzis [24] for the first record of the congeneric $S$. ovalis in the Aegean Sea, which was also interpreted as an expansion of the geographical distribution of the species. Therefore, though the present record of $S$. medusophagus along the Italian peninsular coast of the Central Tyrrhenian Sea is not an extension of the species range, its abundance should be evaluated on a continuous basis as it could be an indicator or example of the biological consequences of environmental and climatic change [21].

The sequences obtained in this study are the first mitochondrial sequences for the species, and thus constitute a useful identification tag for future samples. Meanwhile, they can help to clarify the phylogenetic status of the genus Schedophilus Cocco, 1839, of which $S$. medusophagus is the type species. This genus currently includes nine species (Froese and Pauly, www.fishbase.org, version 11/2010), with a diverse array of forms that show a morphological dichotomy. One form is hard-spined and firm-fleshed (e.g. S. ovalis and S. velaini) and the other is weak-spined and soft-fleshed (e.g. S. medusophagus and S. huttoni) $[17,25]$. Thus, the breadth and validity of the genus has been debated by various authors [e.g. 26-28]. In this context, an allozyme survey of 11 stromateoid species from Australian waters [25], including two Schedophilus species, clearly evidenced the separate clustering of the weakspined S. huttoni and the hard-spined S. labyrinthicus, and the non monophyly of the genus. Bolch et al. [25] therefore proposed reconsidering the composition of the genus and suggested that the hard-spined, firm-fleshed group might be more correctly represented as a distinct centrolophid genus. They also emphasized that the taxonomic revision of the genus was hampered by the rarity of Schedophilus material, particularly of the type species S. medusophagus [25].

The BLAST search results obtained in the present study using the COI sequence and the BOLD database (Table 3) might also be considered congruent with the hypothesis of a non-monophyletic status of the genus Schedophilus and the existence of two groups within it. Indeed, the studied specimen of $S$. medusophagus shows the highest similarity value $(98 \%)$ with the weakspined S. huttoni species, lower values (91\%) with the remaining hard-spined Schedophilus species, and values intermediate to these with two non-congeneric species of Centrolophidae, lcichthys lockingtoni and Tubbia tasmanica. As not all the COI sequences of the BOLD database are listed in Genbank, we were not able to perform any phylogenetic analyses within this study. However, in the phenetic BOLD Taxonld tree (not shown) $S$. medusophagus and $S$. huttoni are included in the same cluster, which is separate from the other Schedophilus species. These latter are instead grouped with other Centrolophidae species.

From a methodological point of view, the need for integration between the existing databases was apparent. In addition to the incomplete overlap between the BOLD and the GenBank sequences, the nomenclature reported in the BOLD and FishBase databases is not always congruent. For example, S. labyrinthicus and S. velaini are considered as synonyms in FishBase (Froese and Pauly, www.fishbase.org, version 11/2010) and as separate species in BOLD.

In conclusion, the benefits of the application of molecular tools to complement the traditional taxonomic data in the present study are unquestionable. However, though the application of the molecular approach is easier and faster than the morphological one, the resolving power of the molecular approach is also strictly correlated with taxon coverage, which is still limited, especially when rare species are considered.

\section{Acknowledgements}

We would like to thank Ettore Spina, a fisherman in Anzio, for his skills in identifying a biological "novelty" and for his curiosity and willingness to understand it better. 
[1] Strauss R.E., Bond C.E., Taxonomic methods: morphology, In: Schreck C.B., Moyle P.B., (Eds.), Methods for fish biology, American Fisheries Society, Maryland, 1990

[2] Kon T., Yoshino T., Mukai T., Nishida M., DNA sequences identify numerous cryptic species of vertebrate: a lesson from the gobioid fish Schindleria, Mol. Phylogenet. Evol., 2007, 44, 53-62

[3] Teletchea F., Molecular identification methods of fish species: reassessment and possible applications, Rev. Fish Biol. Fisher., 2009, 19, 265-293

[4] Hebert P.D.N., Cywinska A., Ball S.L., deWaard R., Biological identifications through DNA barcodes, Proc. R. Soc. Lond. B, 2003, 270, 313-321

[5] Tautz D., Arctander P., Minelli A., Thomas R.H., Vogler A.P., A plea for DNA taxonomy, Trends Ecol. Evol., 2003, 18, 70-74

[6] Teletchea F., After 7 years and 1000 citations: comparative assessment of the DNA barcoding and the DNA taxonomy proposals for taxonomists and non-taxonomists, Mitochondr. DNA, 2010, 21, 206-226

[7] Agnèse J.F., Teugels G.G., Galbusera P., Guyomard R., Volckaert F., Morphometric and genetic characterization of sympatric populations of Clarias gariepinus and C. anguillaris from Senegal, J. Fish Biol., 1997, 50, 1143-1157

[8] Tseng M.C., Jean C.T., Tsai W.L., Chen N.C., Distinguishing between two sympatric Acanthopagrus species from Dapeng Bay, Taiwan, using morphometric and genetic characters, J. Fish Biol., 2009, 74, 357-376

[9] Aljanabi S.M., Martinez I., Universal and rapid saltextraction of high quality genomic DNA for PCRbased techniques, Nucl. Acids Res., 1997, 25, 4692-4693

[10] Miya M., Nishida M., Use of mitogenomic information in teleostean molecular phylogenetics: a tree-based exploration under the maximumparsimony optimality criterion, Mol. Phylogenet. Evol., 2000, 17, 437-455

[11] Milana V., Sola L., Congiu L., Rossi A.R., Mitochondrial DNA in Atherina (Teleostei, Atheriniformes): differential distribution of an intergenic spacer in lagoon and marine forms of Atherina boyeri, J. Fish Biol., 2008, 73, 1216-1227

[12] Cantatore P., Roberti M., Pesole G., Ludovico A., Micella F., Gadaleta M.N., et al., Evolutionary analysis of the cytochrome $b$ sequences in some Perciformes: evidence for a slower rate of evolution than in mammals, J. Mol. Evol., 1994, 39, 589-597
[13] Ward R.D., Zemlak T.S., Innes B.H., Last P.R., Hebert P.D.N., DNA barcoding Australia's fish species, Phil. Trans. R. Soc. B, 2005, 360, 1847-1857

[14] Astolfi L., Dupanloup L., Rossi R., Bisol P.M., Faure E., Congiu L., Mitochondrial variability of sand smelt Atherina boyeri populations from north Mediterranean coastal lagoons, Mar. Ecol. Prog. Ser., 2005, 297, 233-243

[15] Thompson J.D., Gibson T.J., Plewniak F., Jeanmougin F., Higgins D.G., The CLUSTAL X windows interface: flexible strategies for multiple sequence alignment aided by quality analysis tools, Nucl. Acids Res., 1997, 25, 4876-4882

[16] Tortonese E., Fauna d'Italia: Pesci Ossei (Fauna of Italy: Osteichthyes), part 2, Calderini, Bologna, 1975, (in Italian)

[17] Haedrich R.L., Centrolophidae, In: Whitehead P.J.P., Bauchot M.L., Hureau J.C., Nielsen J., Tortonese E., (Eds.), Fishes of the North-eastern Atlantic and the Mediterranean, vol. 3, UNESCO, Paris, 1986

[18] Bauchot M.L., Centrolophidae, In: Fischer W., Bauchot M.L., Schneider M., (Eds.), Fiches FAO d'identification des espèces pour les besoins de la pêche, Révision 1, Méditerranée et mer Noire, Zone de Pêche 37 (FAO species identification sheets for fishery purposes. Mediterranean and Black Sea, Fishing Area 37), FAO, Rome, 1987, (in French)

[19] Haedrich R.L., Centrolophidae. Medusafishes (ruffs, barrelfish), In: Carpenter K.E., (Ed.), The living marine resources of the Western Central Atlantic, vol. 3: Bony fishes part 2 (Opistognathidae to Molidae), sea turtles and marine mammals, FAO, Rome, 2002

[20] Bini G., Centrolophidae, In: Atlante dei Pesci delle coste Italiane (Nearshore Fish Atlas of Italy), vol. 6: Osteitti (Osteichthyes), Mondo Sommerso, Milano, 1968 (in Italian)

[21] Dulčić J., First record of the cornish blackfish Schedophilus medusophagus (Pisces: Centrolophidae) larvae from the Adriatic Sea, J. Mar. Biol. Assoc. UK, 1998, 78, 1035-1038

[22] Ninni E., Catalogo dei pesci del Mare Adriatico (Checklist of fishes of the Adriatic Sea), Bertotti, Venezia, 1912, (in Italian)

[23] Onofri I., The rare saw-cheeked fish (Schedophihis medusophagus Cocco, 1839) (Pisces: Centrolophidae) in the central Adriatic, Malice Srpske, 1986, 70, 135-141

[24] Corsini-Foka M., Frantzis A., First documented record of imperial blackfish, Schedophilus ovalis 
(Actinopterygii: Perciformes: Centrolophidae), in the Aegean Greek waters, Acta Ichthyol. Piscat., 2009, 39, 47-49

[25] Bolch C.J.S., Ward R.D., Last P.R., Biochemical systematics of the marine fish family Centrolophidae (Teleostei: Stromateoidei) from australian waters, Aust. J. Mar. Fresh. Res., 1994, 45, 1157-1172

[26] Ahlstrom E.H., Butler J.L., Sumida B.Y., Pelagic stromateoid fishes (Pisces, Perciformes) of the eastern Pacific: kinds, distributions and early life histories and observations on five of these from the north west Atlantic, Bull. Mar. Sci., 1976, 26, 285-402

[27] McDowall R.M., The centrolophid genus Tubbia (Pisces: Stromateoidei), Copeia, 1979, 1979, 733738

[28] McDowall R.M., The centrolophid fishes of New Zealand (Pisces: Stromateoidei), J. Roy. Soc. New Zeal., 1982, 12, 103-142 